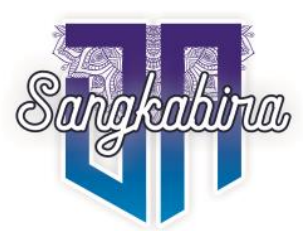

Vol. 2, No. 1, Desember 2021

\title{
PELATIHAN TEKNIK PERHITUNGAN UPAH MINIMUM REGIONAL (UMR) PADA ANGGOTA TRIPARTIT KOTA MATARAM BERDASARKAN PERATURAN PEMERINTAH NOMOR 78 TAHUN 2015
}

\author{
Siti Fatimah \\ Fakultas Ekonomi dan Bisnis Universitas Mataram \\ sitifatimah@unram.ac.id \\ Tuty Handayani \\ Fakultas Ekonomi dan Bisnis Universitas Mataram \\ sifa25023@gmail.com
}

Info Artikel

Diterima:

22-11-2021

Direvisi:

28-12-2021

Diterbitkan:

28-12-2021

\begin{abstract}
Abstrak
Pengabdian pada Masyarakat ini berjudul Pelatihan Teknik Perhitungan Upah Minimum Regional (UMR) pada Anggota Tripartit Kota Mataram. Adapun tujuan Pengabdian ini adalah: (1) Untuk mengetahui cara perhitungan kebutuhan hidup layak pekerja lajang dengan masa kerja kurang dari satu tahun, (2) Untuk mengetahui tata cara perhitungan Upah Minimum regional (UMR) bagi pekerja lajang dengan masa kerja kurang dari satu tahun dan (3) Memberikan panduan kepada unsur tripartit agar mempunyai dasar yang akan dipedomani guna penetapan Upah Minimu Regional (UMR) Kota Mataram dimasa yang akan atang.

Adapun metode pelatihan yang digunakan disamping menggunakan tutorial, diskusi-diskusi yang juga lebih ditekankan pada latihan-latihan terhadap beberapa hasil survey terdahulu tentang: bagaimana tata cara penetapan kebutuhan hidup layak (KHL) berdasarkan hasil survey harga pasar khusunya kebutuhan pokok. Selanjutnya dari hasil penetapan $\mathrm{KHL}$ selanjutnya bagaimana tata cara menetapkan Upah Minimum Regional (UMR). Selanjutnya melalui latihan juga dilakukan diskusi terhadap hasil yang dikerjakan oleh setiap peserta agar diperoleh gambaran tentang hasil analisis yang lebih akurat.

Setelah dilakukan survey terhadap ke 60 jenis barang kebutuhan masyarakat tersebut secara priodik per 3 bulan atau 4 kali selama satu tahun, maka selanjutnya dilakukan perhitungan dengan mempertimbangkan ada 4 kriteria sebagai berikut: (1) Laju pertumbuhan ekonomi daerah, (2) Tingkat Produktivitas (3) Tingkat inflasi daerah dan (4) Kelompok usaha Marjinal daerah. Adapun hasil nilai Upah Minimu Regional (UMR)
\end{abstract}


berdasarkan hasil analisis data dan dengan mempertimbangkan keempat kriteria tersebut maka dapat disajikan nilai upah minimum regional (UMR) tahun 2017 - 2021 adalah sebagai berikut: Rp 1.714.216, Rp 1.863.524, Rp 2.013.165 dan Rp 2.184.485,- artinya terus mengalami peningkatan setiap tahunnya. Sedangkan untuk Tahun 2021 tidak mengalami kenaikan yang disebabkan oleh kondisi masa pandemic Corona Virus Disease 2019 atau (Covid 19) dan sesuai Surat Edaran Menteri Ketenagakerjaan Nomor: M/11/HK.04/X/2020 untuk tidak menaikkan Upah Minumum Regional Tahun 2021

Kata Kunci: Upah Minimun regional, Triparti, Peraturan pemerintah

DOI: $10.29303 / a b d i m a s s a n g k a b i r a . v 2 i 1.83$

\section{PENDAHULUAN \\ Analisis Situasi}

Sebelum pemberlakuan Peraturan Pemerintah Nomor: 78 Tahun 2015, yang menjadi acuan penentuan tingkat upah atau Upah Minimum Regional (UMR) didasarkan pada 4 (empat) kriteria seperti: Pertumbuhan ekonomi, tingkat inflasi, usaha marginal dan produktivitas sesuai dengan Undang-undang Nomor 13 Tahun 2003. Dasar penentuan upah regional tersebut harus ditentukan berdasarkan atas survey harga atas penetapan nilai kebutuhan hidup layak (KHL) sesuai amanat Peraturan Menteri Tenaga Keraj dan Tansmigrasi Republik Indonesia Nomor; PER-17/MEN/VIII/2005. Kebutuhan Hidup Layak (KHL) merupakan suatu standar kebutuhan yang harus dipenuhi oleh seorang pekerja/buruh lajang untuk dapat hidup layak baik secara fisik dan sosial, untuk kebutuhan 1 (satu) bulan. Terkait dengan survey tersebut di atas pelaksanaannya dilakukan oleh unsur Tripartit yang dibentuk oleh Dewan Pengupahan daerah (Kota Mataram).

Dilihat dari sudut pandang survey KHL yang merupakan peningkatan dari kebutuhan hidup minimum, maka survey tersebut dilakukan oleh unsur Tripartit yang meliputi: unsur pemerintah, unsur pengusaha dan unsur pekerja/buruh. Penetapan unsur tersebut didasari atas kepentingan yang sama guna lebih mengetahui dan memahami filosofi dasar yang digunakan dalam penentuan Upah minimum Regional (UMR). Berdasarkan hasil survey harga yang dilakukan unsur Tripartit Dewan pengupahan kota dapat menetapkan nilai kebutuhan hidup layak. Nilai KHL tersebut akan digunakan sebagai salah satu bahan pertimbangan dalam penetapan upah minimum.

Penetapan upah minimum tersebut berlaku bagi pekerja/buruh dengan masa kerja kurang dari 1 (satu) tahun. Sedangkan upah bagi pekerja/buruh dengan masa kerja 1 (satu) tahun atau lebih dirundingkan 


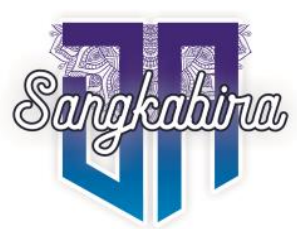

Vol. 2, No. 1, Desember 2021

secara bipartite (unsur pengusaha dengan buruh/pekerja) atau serikat pekerja/serikat buruh dengan pengusaha di perusahaan yang bersangkutan. Selain menggunakan survey harga sebagai salah satu dasar pertimbangan penetapan Upah minimum regional (UMR) juga digunakan unsur produktivitas, pertumbuhan ekonomi dan usaha yang paling tidak mampu(marginal) sebagai unsur yang menjadi bahan pertimbangan penetapan Upah Minimum regional (UMR). Produktivitas sebagaimana dimaksud di atas merupakan hasil perbandingan antara jumlah Produk Domestic Regional Brutto (PDRB) dengan jumlah tebnaga kerja pada priode yang sama. Sementara pertumbuhan ekonomi sebagaimana dimaksud di atas merupakan pertumbuhan nilai Product Domestic Regional Brutto (PDRB).

Guna mencapai hasil survey yang memadai sesuai kaedah penelitian maka ditentukan obyek survey sesuai kaedah survey yang benar dengan menentukan lokasi secara purposive sampling agar dapat mewakili seluruh unsur populasi sehingga hasilnya dapat merefresentasikan seluruh kondisi pasar yang ada di Kota Mataram. Adapun unsur survey dengan melibatkan seluruh unsur tripartit yang berpedoman pada daftar kuesioner yang sudah disusun terlebih dahulu. Adapun komponen-komponen yang dilakukan pendataan meliputi komponen kebutuhan hidup layak yang terdiri atas; unsur makanan dan minuman, sandang, perumahan, pendidikan, kesehatan, transportasi, rekreasi dan tabungan (Permen Tenaga Kerja dan transmigrasi RI). Terkait dengan hal tersebut di atas maka berdasarkan kenyataan di lapangan tidak semua unsur triparti mampu untuk melakukan analisis hasil survey untuk menetukan kebutuhan hidup layak sebagai salah satu unsur penentuan Upah minimum regional (UMR). Untuk itu maka sangat perlu dilakukan pelatihan untuk melakukan analisis data hasil survey agar dapat melakukan penentuan dan penetapan Upah Minimum Regional Kota Mataram. Diharapkan melalui kegiatan pelatihan ini seluruh unsur triparti dapat memahami tehnis penyusunan dan perhitungan Upah Minimum Regional Kota Mataram.

\section{Perumusan Masalah}

Adapun perumusan masalah dalam pengabdian masyarakat ini adalah sebagai berikut:

1. Bagaimana cara menentukanUpah Minimum Regional (UMR) Kota Mataram berdasarkan Peraturan Pemerintah Nomor: 78 Tahun 2015 untuk tenaga kerja/buruh lajang dengan masa kerja kurang dari satu tahun.

2. Bagaimana cara menganalisis hasil perhitungan kebutuhan hidup layak $(\mathrm{KHL})$ Kota Mataram dan selanjutnya menetapkan Upah Minimum Regional (UMR). 


\section{SOLUSI DAN TARGET LUARAN Solusi}

Sebelum menetapkan target luaran, terlebih dahulu ditentukan target sasaran dalam pelatihan ini yang melibatkan unsur Serikat Pekerja Seluruh Indonesia (SPSI) yang mewakili unsur buruh/karyawan, unsur Asosiasi Pengusaha Indonesia (Apindo) dan unsur tehnis yang berasal dari Disnakertrans Kota Mataram. Adapun yang menjadi target luaran pelatihan ini yaitu semua unsur dalam Tripartit baik unsur SPSI, unsur Apindo dan Dinas Tenaga Kerja dan transmigrasi Kota Mataram. Keterlibatan semua unsur ini sangat diperlukan agar mempunyai pemahaman yang sama tentang bagaimana tata cara penentuan Kebutuhan Hidup layak (KHL) yang dilakukan melalui survey sebanyak 62 jenis barang kebutuhan pokok setiap orang. Sehingga dengan diketahuinya besaran $\mathrm{KHL}$ maka perhitungan dan penetapan Upah Minimum Regional (UMR) Kota Mataram dapat dilakukan dengan aman.

\section{Target Luaran}

Adapun yang menjadi target luarannya adalah terciptanya system perhitungan Upah Minimum Regional (UMR) yang berkeadilan serta memperhatikan nasib para karyawan terutama yang masa kerjanya 1 (satu) tahun kebawah dan para pengusaha (investor).

Adapun yang dilibatkan dalam pelatihan ini terdiri dari berbagai unsur terkait yang tergabung dalam kelompok Tripartit seperti asosiasi buruh/karyawan (SPSI), unsur pengusaha (APINDO) dan unsur tehnis di Depnakertans Kota Mataram.

\section{METODE PELAKSANAAN} Metode Pelaksanaan

Adapun metode pelatihan yang digunakan dalam kegiatan ini disamping menggunakan tutorial, diskusi-diskusi yang lebih ditekankan pada latihan-latihan terhadap beberapa hasil survey terdahulu tentang : bagaimana tata cara penetapan kebutuhan hidup layak (KHL) berdasarkan hasil survey harga pasar khusunya kebutuhan pokok. Selanjutnya dari hasil penetapan KHL selanjutnya bagaimana tata cara menetapkan Upah Minimum Regional (UMR). Selanjutnya melalui latihan juga dilakukan dan diskusi terhadap hasil yang dikerjakan oleh setiap peserta agar diperoleh hasil analisis yang lebih akurat dan mendapatkan gambaran tentang besaran tiap Upah Minimum Regional (UMR) setiap tahunnya. 


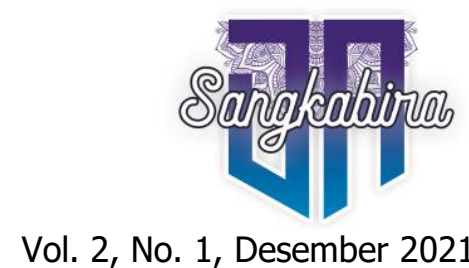

\section{HASIL DAN PEMBAHASAN}

\section{Survey Harga Kebutuhan Pokok}

Sebelum melakukan perhitungan dan analisis data terlebih dahulu dilakukan survey harga terhadap kebutuhan masyarakat yang meliputi: (1) makanan dan minuman yang terdiri dari 11 jenis, (2) sandang yang terdiri dari 11 jenis, (3) perumahan yang terdiri dari 26 jenis, (4) pendidikan yang terdiri dari 2 jenis, (5) kesehatan yang terdiri dari 5 jenis, (6) transportasi 1 jenis (7) rekreasi dan tabungan yang terdiri dari 2 jenis barang kebutuhan masyarakat. Dari semua jenis kebutuhan di atas terbagi kedalam 60 jenis barang. Pelaksanaan survey dilakukan pada berbagai pasar yang ada di kota Mataram. Dalam penentuan lokasi pasar dilakukan secara purposive sampling dengan memperhatihan perwakilan daerah/wilayah pasar seperti:

- Wilayah timur kota Mataram diwakili oleh pasar Cakra, sayang-sayang dan Abian Tubuh.

- Wilayah tengah diwakili oleh pasar Dasan Agung dan pasar Cemara.

- Wilayah barat diwakili oleh pasar ACC dan pasar Kebon Roek.

Dari hasil survey dihasilkan masing-masing besarnya nilai KHL setiap wilayah ditunjukkan dalam tabel di bawah:

Tabel 1. Besarnya nilai Kehidupan Hidup Layak (KHL) Pada Berbagai Lokasi Survey (Pasar) Tahun 2017-2021

\begin{tabular}{|c|l|c|c|c|c|c|}
\hline No. & $\begin{array}{c}\text { Nilai KHL di } \\
\text { Berbagai } \\
\text { Lokasi Pasar }\end{array}$ & $\begin{array}{c}\text { Tahun } \\
\mathbf{2 0 1 7} \\
\mathbf{( R p )}\end{array}$ & $\begin{array}{c}\text { Tahun } \\
\mathbf{2 0 1 8} \\
\mathbf{( R p )}\end{array}$ & $\begin{array}{c}\text { Tahun } \\
\mathbf{2 0 1 9} \\
\mathbf{( R p )}\end{array}$ & $\begin{array}{c}\text { Tahun } \\
\mathbf{2 0 2 0} \\
\mathbf{( R p )}\end{array}$ & $\begin{array}{c}\text { Tahun } \\
\mathbf{2 0 2 1} \\
\mathbf{( R p )}\end{array}$ \\
\hline 1 & Cakranegara & 1.378 .691 & 1.418 .713 & 1.631 .521 & 1.876 .249 & 2.157 .686 \\
\hline 2 & Sayang-sayang & 1.378 .864 & 1.393 .702 & 1.602 .757 & 1.843 .170 & 2.119 .645 \\
\hline 3 & Abian Tubuh & 1.374 .059 & 1.382 .692 & 1.590 .095 & 1.828 .609 & 2.102 .900 \\
\hline 4 & Dasan Agung & 1.409 .364 & 1.426 .692 & 1.640 .696 & 1.886 .800 & 2.169 .820 \\
\hline 5 & Cemare & 1.384 .556 & 1.343 .934 & 1.545 .524 & 1.777 .352 & 2.043 .954 \\
\hline 6 & ACC & 1.380 .074 & 1.402 .291 & 1.612 .634 & 1.854 .529 & 2.132 .708 \\
\hline 7 & Kebon Roek & 1.377 .324 & 1.387 .364 & 1.595 .486 & 1.834 .806 & 2.110 .026 \\
\hline & J u m la h & $\mathbf{9 . 6 8 2 . 9 6 8}$ & $\mathbf{8 . 3 2 8 . 6 9 6}$ & $\mathbf{1 1 . 2 1 8 . 7 1 3}$ & $\mathbf{1 2 . 9 0 1 . 5 1 5}$ & $\mathbf{1 4 . 8 3 6 . 7 3 9}$ \\
\hline & Rata-rata & $\mathbf{1 . 3 8 3 . 2 8 1}$ & $\mathbf{1 . 1 8 9 . 8 1 3}$ & $\mathbf{1 . 6 0 2 . 6 7 3}$ & $\mathbf{1 . 8 4 3 . 0 7 3}$ & $\mathbf{2 . 1 1 9 . 5 3 4}$ \\
\hline
\end{tabular}

Sumber: Data Primer diolah

Berdasarkan data pada tabel di atas, maka besarnya nilai Kehidupan Hdup Layak (KHL) di kota Mataram dari tahun ke tahun mengalami peningkatan seiiring dengan peningkatan harga-harga kebutuhan $\mathrm{p}$ okok sehari-hari. Peningkatan harga dimaksud tidak lain disebabkan oleh terjadinya inflasi dari waktu ke waktu. Hal inilah yang menyebabkan terjadinya kenaikan kebuthan hidup layak dari tahun ke tahun. Dilihat dari Tahun 2017-2021 besarnya rata-rata nilai kehidupan hidup layak (KHL) kota Mataram sebesar Rp 1.383.281, Rp1.189.813, Rp 1.602.673, Rp 
1.843.073,- dan Rp 2.119.534 atau rata-rata peningkatannya sebesar 15,00 persen tiap tahunnya.

\section{Penentuan dan Penetapan Upah Minimum Regional}

Setelah dilakukan survey terhadap ke 60 jenis barang kebutuhan masyarakat tersebut secara priodik per 3 bulan atau 4 kali selama satu tahun, maka selanjutnya dilakukan perhitungan dengan mempertimbang kan ada 4 kriteria sebagai berikut: (1) Laju pertumbuhan ekonomi daerah, (2) Tingkat Produktivitas (3) Tingkat inflasi daerah dan (4) Kelompok usaha marjinal daerah.

Adapun hasil nilai Upah Minimu Regional (UMR) berdasarkan hasil analisis data tabel 1 diatas dan dengan mempertimbangkan keempat kriteria tersebut maka dapat disajikan nilai Upah Minimum Regional (UMR) Tahun 2017 - 2021 adalah sebagai berikut:

Tabel : 2. Besarnya Nilai UMR Kota Mataram Tahun 2017-2021

\begin{tabular}{|c|c|c|c|c|c|c|}
\hline No. & Keterangan & $\begin{array}{l}\text { Tahun } \\
2017 \\
\text { (Rp) }\end{array}$ & $\begin{array}{l}\text { Tahun } \\
2018 \\
\text { (Rp) }\end{array}$ & $\begin{array}{c}\text { Tahun } \\
2019 \\
\text { (Rp) }\end{array}$ & $\begin{array}{l}\text { Tahun } \\
2020 \\
\text { (Rp) }\end{array}$ & $\begin{array}{c}\text { Tahun } \\
2021 \\
\text { (Rp) }\end{array}$ \\
\hline 1. & Nilai UMR & 1.714 .216 & 1.863 .524 & 2.013 .165 & 2.184 .485 & 2.184 .485 \\
\hline
\end{tabular}

Sumber: Data Primer diolah (Hasil analisis data KHL)

Berdasarkan data tabel di atas nampak dengan jelas bahwa nilai Upah Minimum Regional (UMR) setiap tahun mengalami peningkatan seiring dengan peningkatan pertumbuhan ekonomi, tingkat inflasi, produktivitas tenaga kerja dan kualifikasi usaha marjinal sesuai dengan kriteria yang diatur dalam permen No: PER-17/MEN/VIII/2005. Secara kuantitatif besaran Upah Minimum Regional (UMR) Kota Mataram terhitung sejak tahun 2017- 2021 sebesar, Rp 1.714.216, Rp 1.863.524, Rp2.013.165, Rp 2.184.485, dan tahun 2021 tetap sebesar Rp 2.184.485.

Sebagai bahan informasi bahwa penetapan Upah Minimum Regional (UMR) tahun 2021 selama masa pandemic Corona Virus Disease 2019 atau (Covid 19) besarannya tetap seperti tahun 2020, sesuai Surat Edaran Menteri Ketenagakerjaan Republik Indonesia Nomor: M/11/HK.04/X/2020, tanggal 26 Oktober 2020 tentang Penetapan Upah Minimum Tahun 2021 pada Masa Pandemi Virus Disease 2019 atau (Covid 19). Kebijakan penetapan besaran Uapah Minimum Regional (UMR) tahun 2021, didasari atas pertimbangan bahwa pandemic Covid 19 telah berdampak pada kondisi prekonomian dan kemampuan perusahaan dalam memenuhi hak pekerja/buruh termasuk dalam membayar upah. Dalam rangka memberikan perlindungan dan kelangsungan bekerja bagi pekerja/buruh serta menjaga kelangsungan usaha, perlu dilakukan penyesuaian terhadap penetapan upah minimum pada situasi pemulihan ekonomi di masa pandemic Covid 19. 


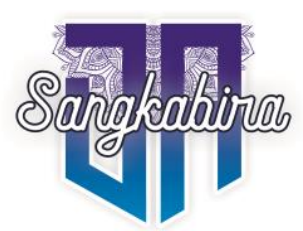

Vol. 2, No. 1, Desember 2021

Adapun pointer/isi yang tertuang dalam Surat Edaran Menteri Ketenagakerjaan Nomor: M/11/HK.04/X/2020, diminta kepada Gubernur Seluruh Indonesia untuk:

1. Melakukan penyesuaian penetapan nilai Upah Minimum Tahun 2021 sama dengan nilai Upah Minimum Tahun 2020.

2. Melaksanakan penetapan Upah Minimum setelah Tahun 2021 sesuai ketentuan peraturan perundang-undangan

3. Menetapkan dan mengumumkan Upah Minimum Provinsi tahun 2021 pada tanggal 31 Oktober 2020.

Surat Edaran Menteri Ketenagakerjaan Inilah yang menjadi dasar pijakan yuridis bagi tim anggota Tripartit Kota Mataram untuk mengambil kebijakan penetapan Upah Minimum Regional (UMR) Kota Mataram Tahun 2021 sama dengan tahun sebelumnya.

\section{KESIMPULAN DAN SARAN Kesimpulan}

Besaran nilai Upah Minimum Regional (UMR) Kota Mataram.dari tahun 2017 sampai dengan tahun 2021 selalu mengalami kenaikan yang didasarkan atas pertimbangan pertumbuhan ekonomi, produktivitas, inflasi dan usaha marjinal. Secara kuantitatif kenaikan Upah Minimum Regional Kota Mataram 5 (lima) tahun terakhir rata-rata sebesar 15,00 persen terkecuali pada tahun 2021 yang tidak mengalami kenaikan disebabkan oleh masa pandemic Corona Virus Disease 2019 atau (Covid 19) dan sesuai Surat Edaran Menteri Ketenagakerjaan Nomor: M/11/HK.04/X/2020 untuk tidak menaikkan Upah Minumum Regional Tahun 2021.

\section{Saran}

Kedepan untuk memenuhi rasa keadilan sebaiknya penetapan besarnya Upah Minimum Regional (UMR) perlu dilakukan peninjauan kembali, karena tiap sector membawa konsekuensi beban dan taggung yang berbeda baik secara fisik maupun secara moral. Dengan terjadinya disparitas beban dan tanggung jawab ini, maka hendaknya penetapan Upah Minimum Regional disamping mengacu kembali pada Undang-Undang Ketenagakerjaan Nomor: 13 tahun 2003 dan permen No: PER17/MEN/VIII/2005, dengan tetap mengacu pada per Sektor ekonomi.

\section{DAFTAR PUSTAKA}

2005. Pedoman Survey Harga Penetapan Nilai Kebutuah Hidup Layak (KHL) Peraturan Menteri Tenaga Kerja dan Transmigrasi Republik Indonesia No: PER-17/MEN/VIII/2005.

2007. Undang-Undang Keternagakerjaan Republik Indonesia, Nomor 13 Tahun 2003, Jakarta.

2010. Pembentukan dan Peningkatan Peran Lembaga Kerjasama

Tripartit Provinsi Kabupaten/Kota. Peraturan bersama Menteri 
Siti Fatimah dan Tuti Handayani: Pelatihan Teknik Perhitungan Upah Minimum .........

Tenaga Kerja dan Transmigrasi No: PER-04/MEN/II/2010 dan Menteri Dalam Negeri No: 17 Tahun 2010.

2011. Penetapan Upah Mínimum Kota (UMK) Mataram Tahun 2011. Keputusan Gubernur Provinsi Nusa Tenggara Barat No: 146/Tahun 2011.

2013. Peraturan Menteri Tenaga Kerja dan TransmigrasI

Nomor: 7 Tahun 2013 Tentang Upah Minimum, Jakarta

2015. Peraturan Pemerintah Nomor: 78 Tahun 2015 tentang Dasar Penetapan Upah Minimum Regional, Jakarta. 